\title{
IS THERE A CASE FOR PUBLIC PROVISION OF PRIVATE GOODS IF PREFERENCES ARE Heterogeneous? AN EXAMPLE WITH DAY CARE
}

\author{
SÖREN BLOMQUIST \\ VIDAR CHRISTIANSEN \\ CESIFO WORKING PAPER NO. 938 \\ CATEGORY 1: PUBLIC FinANCE \\ MAY 2003 \\ An electronic version of the paper may be downloaded \\ - from the SSRN website: www.SSRN.com \\ - from the CESifo website: www.CESifo.de
}




\title{
IS THERE A CASE FOR PUBLIC PROVISION OF PRIVATE GOODS IF PREFERENCES ARE HETEROGENEOUS? AN EXAMPLE WITH DAY CARE
}

\begin{abstract}
A strong case for public provision of certain private goods has been established for an economy in which individuals have homogeneous preferences but differ in skill levels. There has been a critique of this model/mechanism arguing that heterogeneous preferences at a given skill level would invalidate the mechanism, implying that public provision of private goods is merely of theoretical, not of practical interest. The argument is that if the public provision level is set so as to fit the low skill person with a high preference for the publicly provided good, the low skill person with a low preference for the good comes out worse than in a system without public provision. In this paper we take this critique seriously and investigate if a public provision scheme can be constructed so that we obtain a strict Pareto improvement when going from a pure tax/transfer system to the public provision scheme even if preferences are heterogeneous. We find that heterogeneous preferences do not invalidate the benefits of publicly provided private goods. We also characterise the optimum tax and public provision policy.
\end{abstract}

JEL Code: H21, H42, I38.

Keywords: public provision, private goods, in-kind transfer, heterogeneous preferences, day care.

Sören Blomquist

Department of Economics

Uppsala University

Box 513

75120 Uppsala

Sweden

Soren.Blomquist@nek.uu.se
Vidar Christiansen

Department of Economics

University of Oslo

Box 1095

Blindern 0317 Oslo

Norway

Vidar.Christiansen@econ.uio.no 


\section{Introduction}

A strong case for public provision of certain private goods has been established in an economy in which individuals have homogeneous preferences but differ in skill levels. ${ }^{3}$ A non-linear, redistributive income tax is imposed under the asymmetric information that knowledge of who is high-skilled and who is low-skilled is private information not available to the government. The tax schedule must then be designed subject to the self-selection constraint ensuring that a highskilled person does not select an income point intended for the low-skilled person. If the highskilled person were to mimic, he would obtain more leisure than the low-skilled person with the same income as, being more productive, the high-skilled person could earn the same income in less time. However, if some of the transfer is given in kind, it may be of less value to the mimicker than to the genuine low-skilled type if the good that is transferred is less beneficial to someone who enjoys more leisure. Shifting to a transfer in kind may therefore make mimicking less appealing, and thus alleviate the self-selection constraint and enhance welfare. Day care for children may be a striking example of a good suitable for this purpose as a person who works less will need less day care. By pretending to be low-skilled, the high-skilled person will pay the same tax as the low-skilled person, but will obtain a smaller benefit in return.

At seminar presentations this model have sometimes been critized. It has been argued that heterogeneous preferences at a given skill level would invalidate the mechanism, implying that public provision of private goods is merely of theoretical, not of practical interest. The argument is that if the public provision level is set so as to fit the low-skill person with a high preference for the publicly provided good, the low skill person with a low preference for the good comes out worse than in a system without public provision. In this paper we take this critique seriously and investigate if a public provision scheme can be constructed so that we obtain a strict pareto improvement when going from a pure tax/transfer system to the public provision scheme even if preferences are heterogeneuos.

We assume that there are two skill groups, high-skilled and low-skilled individuals. The low-skilled group is assumed to consist of people with heterogeneous preferences: some with a strong preference for leisure, reflecting a strong wish to have time available to spend with the

\footnotetext{
3 Blackorby and Donaldson (1988), Besley and Coate (1991), Blomquist and Christiansen (1995, 1999), Boadway and Marchand (1995), and Cremer and Gahvari (1997) are a few studies showing the benefits of public provision of certain private goods.
} 
children, and some with a weak preference for leisure, reflecting that they are more inclined to pay for child care.

Each agent chooses how much labour to supply and the corresponding consumption level, which depends on the tax liability. The agents of the economy are assumed to have a fixed number of children who must be cared for either by the parents themselves or by day-care centres $^{4}$. We assume that parents do not want to have the children at a day-care centre for more hours then they work. Hence, the need for externally supplied day-care is equal to the number of working hours. The day-care may be paid day-care obtained at market prices, or publicly provided day-care made available free of charge or at a subsidised price. For simplicity we assume that a certain amount of day-care is publicly provided free of charge. An agent can then choose to have exactly this maximum amount of free public day-care, to have a smaller amount, or to take the public provision and then top up in the market at the market price ${ }^{5}$.

As in the conventional two-type model we assume that the government imposes a positive net tax on the high-skilled type and makes a transfer to the low skilled type. The transfer may be in cash or in kind (in terms of day-care).

The low-skill individuals have heterogeneous preferences. In some sense we would like to treat them in an "equal way". However, it is not unambigous how to define this operationally. One could make a case for various definintions. We do not intend to make a contribution to the literature on horizontal equity, but have simply chosen one often used defintion. The net transfers should be the same to all low skill individuals indepedent of what preferences they have. ${ }^{6}$ Hence, we will assume that for horizontal equity reasons the government would like to transfer the same total amount of resources (adding up transfers in kind and in cash) to both preference types. This means that if one type receives a smaller amount of publicly provided day care, he/she must receive a larger transfer in cash.

There is by now a quite large literature on publicly provided private goods. Some of these like Epple and Romano (1996) and Gouveia (1997) give political economy explanations why some private goods are publicly provided. Many of the articles provide normative theories.

\footnotetext{
${ }^{4}$ We perceive each agent as a homogeneous decision maker who may be a single person or a household (couple) facing a single wage-rate and only being concerned with its aggregate leisure, consumption, etc.

${ }^{5}$ The additional amount may conceivably be provided by the same day-care centre, but now charging a market price.

6 This is basically the same defintion of horizontal equity as used by Jordahl and Michelletto (2002) and earlier by Bossert (1995) and Allingham (1975).
} 
Nichols and Zeckhauser (1982) is an early contribution showing how publicly provided goods can be used to achieve redistribution at lower efficiency costs than if only cash transfers were used. Blackorby and Donaldson (1988) and Besley and Coate (1991) showed the usefulnes of publicly provided private goods using models with a limited set of tax instruments. Blomquist and Christiansen (1995) and Boadway and Marchand (1995) showed how publicly provided private goods have a role to play even under conditions where an optimal income tax can be used. These models and arguments have been further developed in for example Cremer and Gahvari (1997), Blomquist and Christiansen (1998a,b), and Boadway et al. (1998). Blomquist and Christiansen (1999) combine the political economy and normative perspectives. In all of these articles it has been assumed that preferences are homogeneous. Heterogeneous preferences have lately been introduced in a few contributions to the optimal tax literature. Sandmo (1993) discussed lump-sum and linear income taxes when people differ only in preferences for leisure. Tarkiainen and Tuomala (1999) and Boadway et al. (2002) studied optimal non-linear income taxation when people differ with respect to skill level as well as preference for leisure. Cuff (2000) has considered heterogenous preferences in the context of workfare.

In section two of the paper we set up the model we will use. Section three contains a description of the optimal income tax, whereas section 4 shows how a strict Pareto improvement can be obtained by supplementing the tax solution with publicly provided day care. In section 5 we characterize the optimal tax - public provision scheme.

\section{The Model}

As is common in the literature on public provision of private goods we use an extension of the Stiglitz-Stern version of the Mirrlees optimal income tax model. ${ }^{7}$ Let $Y^{i}$ and $B^{i}$ denote the gross income and disposable (cash) income, respectively, of a person of type $i$. Moreover, let a low (high) skill level, reflected by a corresponding wage-rate, be denoted by $w^{1}\left(w^{2}\right)$. The labour supply of type $i$ can be expressed as $Y^{i} / w^{i}$. Low and high-skilled types are labelled by superscripts 1 and 2, respectively, and a strong preference for leisure is indicated by a superscript $s$ and a weak preference for leisure by a superscript $w$. Since the distinction applies only to lowskilled persons, we note that it is sufficient to apply a single index to these agents, eg $s$ means strong preference for leisure and (implicitly) a low-skilled type 
A consumer has preferences over consumption, which is equal to disposable income net of the amount spent on day-care, and leisure, which includes time spent with (and looking after) the children and other time for housework, relaxation, etc. We denote the resource cost of day care by $p$ per unit. In a situation without publicly provided day-care the consumption level of type $i$ is then $C^{i}=B^{i}-p Y^{i} / w^{i}$. Since every person has the same time endowment there is a unique relationship between working time and leisure and it is a matter of convenience whether preferences are expressed as preferences for leisure or for work. It follows that if only paid daycare is available, we can write the utility function of a type $i$ individual as $U^{i}\left(B^{i}-p Y^{i} / w^{i}, Y^{i} / w^{i}\right)$.

For a fixed wage rate we can depict an indifference curve in $Y, B$-space (omitting superscripts). An increase in $Y$ will, for a fixed wage rate, provide a measure of increased labour supply, and the curve will tell us the corresponding increase in disposable income that is needed to compensate for the increase in labour supply taking into account both the disutility of labour and the cost of day care incurred when more labour is supplied. An $s$-type will obviously have an indifference curve that is steeper than that of a w-type through any given point in $Y, B$-space as a stronger preference for leisure means requiring a larger compensation to offset the additional disutility from working more.

If an amount of day care, $\bar{x}$, is provided free of charge, the relevant utility function is $U^{i}\left(B^{i}, Y^{i} / w^{i}\right)$ as long as no more than the public provision is needed to obtain the desired amount of labour. If more day care (topping up) is required, the utility becomes $U^{i}\left(B^{i}-p\left(Y^{i} / w^{i}-\bar{x}\right), Y^{i} / w^{i}\right)$. We note that the indifference curve will have a kink at $Y^{i} / w^{i}=\bar{x}$

$\left(Y^{i}=w^{i} \bar{x}\right)$. To the left of $\bar{x}$ an additional unit of labour entails no further cost of day care as it is available free of charge. To the right no further public provision is available, and there is a cost of obtaining additional day care in the market when more labour is supplied. In any case the $s$-type has the steeper indifference curve as compared to the $w$-type. We assume that type 2 has the same preferences as the $w$-type.

\section{The Optimal Income Tax}

${ }^{7}$ See Mirrlees (1971), Stern (1982) and Stiglitz(1982). 
As a starting point we consider the income tax optimum without public provision. This optimum tax problem is, with a few qualifications, analogous to that of Stigliz (1982) and Stern (1982). The approach is to assign to each person a gross and net income bundle that implicitly defines the tax shedule (as for each gross income the difference between gross and net income defines the corresponding tax). An essential feature of the problem is asymmetric information between the respective tax payers and the government about the individual skill leves (wage rates). The implication is that the income points assigned to the respective agents must be chosen subject to the self-selection constraint that no agent could gain by selecting the income point intended for some other agent - described as 'mimicking' of the other agent. The standard assumption is that the tax policy pursues redistribution from high-skilled to low-skilled to the extent that the effective constraint is to avert mimicking by the high-skilled. The efficient tax policy is the one that maximises the welfare of the low-skilled for any utility level assigned to the high-skilled and subject to the self-selection constraint and the government budget constraint. In our problem we also have to add the horizontal equity constraint that low-skilled agents receive the same transfer.

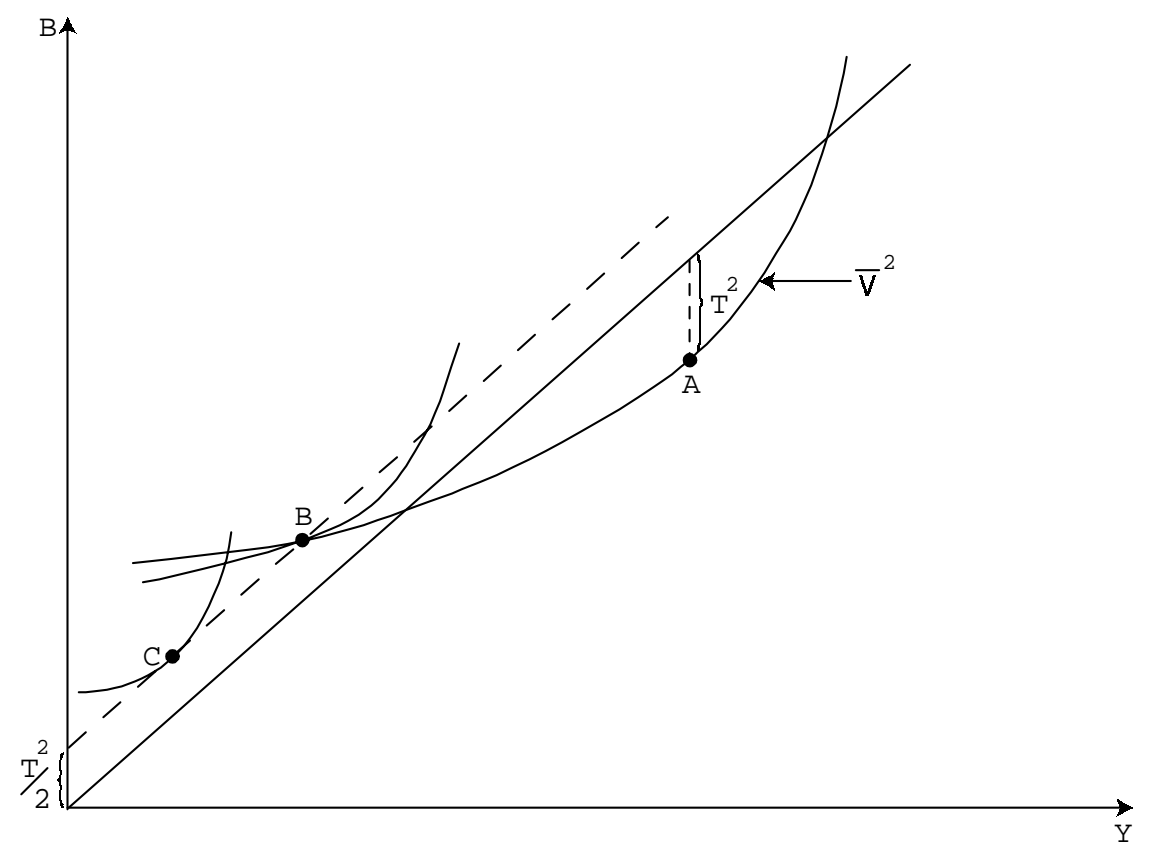

Diagram 1 
We choose not to pursue the analysis of the optimum tax solution algebraically, but present it graphically using diagram 1. We start by pre-assigning some utility level denoted $\bar{V}^{2}$ to the highskilled agent. In order to maximise the resources available for the low-skilled subject to this utility constraint, the tax collected from the high-skill person is maximised. Hence we assign point $A$ to the high-skilled person. This is the point on the indifference curve where its slope is equal to unity, and the vertical distance from the depicted 45-degree line from the origin, which measures the income tax, is maximised. The tax collected is denoted by $T^{2}$. This amount can be used as transfer to the low-skilled persons. For simplicity we normalise the size of the highskilled group to unity and assume the low skilled group is of the same size split equally between the two preference types. Imposing the condition that both receive the same net transfer, they each receive $T^{2} / 2$. For the moment confining attention to the pure budget constraint, the feasible points would be along the dotted straight line. Ideally we would like each low-skilled type to be assigned a point of tangency between the budget line and an indifference curve, and the person with weak preferences for leisure would be assigned a point further to the north-east than the person with strong preferences for leisure. If for both persons there are such point of tangency to the left of point $B$ we have a situation of first best. It is not of interest to study this situation any further.

The interesting cases are those in which the information constraint comes into play, and we have as a binding self-selection constraint that no low-skilled person can be assigned a point to the right of $B$, because then the high-skilled agent 2 would get a higher utiltiy level by mimicking. The two interesting alternatives are $i$. the tangency points with indifference curves along the budget line occur to the right of point $B$ for both persons or $i i$. the point of tangency for the person with weak preferences for leisure is to the right of $B$, and the tangency for the person with strong preference for leisure is located to the left.

In the former case there will be bunching of both low-skilled types at $B$. The marginal rate of substitution (slope of the indifference curve) differs between individuals. Employing the usual measure of marginal tax rates as one minus the MRS (see footnote 8 below), the person with the weaker preference for leisure would face a higher marginal tax than the person with stronger preferences for leisure. Also, the consumption bundle would be less distorted for the person with strong preferences for leisure. In case $i i$ there would be separate points for the two types of low-skill persons. This is the case illustrated in the diagram. The low- skilled person with 
a strong preference for leisure would be undistorted $(M R S=1)$ and face a zero marginal tax at income point $C$. The person with a weak preference for leisure would be distorted and face a positive marginal tax at income point $B(M R S<1)$. There would be a binding self-selection constraint in both cases, and either the consumption-leisure bundle must be distorted for both types (the former case), or the consumption-leisure bundle for the weak preference type must be distorted (the latter case).

\section{A Pareto Improving Public Provision Scheme}

We will next show how a strict Pareto improvement can be obtained by introducing public provision of day-care being financed by (increased) taxes. In case 1, when the low-skilled persons are bunched at income point $B$, the story is basically the same as it would be, had preferences been homogeneous. In the optimal tax situation the demands for day care are given by: $x^{s}=x^{w}=x^{1}=Y^{1} / w^{1}, \quad x^{2}=Y^{2} / w^{2}$ and $x^{m}=Y^{1} / w^{2}$, where $x^{m}$ denotes the demand of the mimicker. We cannot tell whether $x^{s}$ is smaller or larger than $x^{2}$, but we know that $x^{m}<x^{2}$ and $x^{m}<x^{s}$. Set the public provision to $\bar{x}=\min \left(x^{1}, x^{2}\right)$ and decrease the after tax incomes by this amount. The actual person with a higher demand can top up in the market. Hence, the situation for the actual persons is unchanged. However, the mimicker is forced to pay, via taxes, for more day care than he needs and hence gets a decrease in utility, implying that the self-selection constraint will no longer bind. This means that we can change the income point for the low-skill individuals to a point where their consumption-leisure bundle is less distorted. Hence, we can improve welfare for both low skill persons without hurting the high-skill person.

The situation is slightly more complicated in case two. Since the mimicker mimics the low-skill person with weak preferences for leisure the demands are given by $x^{s}=Y^{s} / w^{1}<x^{w}=Y^{w} / w^{1}, x^{2}=Y^{2} / w^{2}$ and $x^{m}=Y^{w} / w^{2}$. As above $x^{m}<x^{2}$ and $x^{m}<x^{w}$. Now, set the public provision to $\bar{x}=\min \left(x^{w}, x^{2}\right)$. The low skill person with a strong preference for lesisure consumes only $x^{s}<\bar{x}$. To leave him at the original utility level his after tax income should only be decreased by the value of his actual day-care consumption. Hence, his new after tax income would be $B^{s}-x^{s}$. The after tax incomes of the low skill person with weak preferences for leisure and for the high skill person are decreased with $\bar{x}$. The actual person with a higher demand for day-care can top up on the market. These changes will leave the 
consumption bundles, and hence utilities, of all actual persons unchanged, but the mimicker's consumption, and hence utility will decrease as he is forced to pay for more day care than he needs in the form of increased taxes. Hence the self-selection constraint is no longer binding, implying that there is scope for changes in the tax system such that utility increases for at least one person without decreasing for the others. One such change would be to make the consumption-leisure point for the low-skill person with a weak preference for leisure less distorted. A technical question; could it be that the high-skill person would like to mimic the low skill person with a strong preference for leisure in the new situation where there is public provision of day care? It is easy to show that this is not the case. The income point for the low skill person with a strong preference for leisure was not attractive to mimic in the optimal tax solution. The rebundling of the after tax income, so that part of it comes in the form of publicly provided day care, makes the point even less attractive to mimic.

In our experiment we have imposed the condition that both low-skill persons should obtain the same net transfer,.i.e., the sum of the cash transfer and the value of the publicly provided and received day care should be the same for the two low-skill types. The total amount transferred from the high-skill person is constant. Hence the net transfer to each one of the two low skill types does not change. In case $i i$ of the optimal tax solutions referred to on p. 6 , the transfer to the person with a strong preference for leisure comes in an undistorted form in the optimal tax solution. Hence, it can not be improved by the public provision scheme. As the experiment is set up the low skill person with a strong preference for leisure neither gains nor loses by the provision scheme. If we abandon the condition that both types should have the same net transfer, we could design a public provision scheme such that both low skill types gain. In such a scheme the low skill type with a strong preference for leisure would be favored in the sense that he obtains a larger net transfer than the weak preference type.

\section{Characterization of the optimal tax-public provision optimum}

There can be two types of optima. One possibility is bunching of the two low-skill types at the same point. The situation is then quite similar to the case with homogeneous preferences. That case has been the topic of earlier studies. We therefore do not describe it further, but concentrate on the other type of optimum where the two low-skill types are allocated different points. 
Recalling the notation introduced in section 2, when there is public provision of day care by an amount $\bar{x}$ the following will be true; $C=B$ if $Y / w \leq \bar{x}$ and $C=B-p(Y / w-\bar{x})$ if $Y / w>\bar{x}$. Substituting these expressions into the utility function we obtain $U^{i}(B, Y)$ if $Y / w \leq \bar{x}$ and $U^{i}\left(B-p\left(Y / w_{i}-\bar{x}\right), Y\right)$ if $Y / w>\bar{x}$.

To characterise the Pareto optimal policy we assume that the policy maker maximizes a weighted sum of the utilities (with weigts $\alpha^{s}$ and $\alpha^{w}$ ) for the low-skill groups subject to a required minimum utility level $\left(\bar{U}^{2}\right)$ for the high-skill group, the self selection constraint, the government budget constraint and the requirement that the net transfer to the two low skill groups be the same. (Since we have imposed the condition that both types of low-skilled persons receive the same net transfer the relative size of $\alpha^{s}$ and $\alpha^{w}$ is of no importance for the solution as long as both weights are positive.) The optimal value of the public provision level is not uniquely determined as all values above $\bar{x}=Y^{w} / w^{1}$ will be equivalent. This is so because of the assumption that individuals only use as much day care as needed for care of the children during the hours of work and the assumption that individuals can top up in the market. To obtain a unique determination we impose the assumption that $\bar{x}$ is set at the lowest of all the equivalent amounts, that is $\bar{x}=Y^{w} / w^{1}$. Given these assumptions the Lagrange function of the optimisation problem will take the form:

$$
\begin{aligned}
& \Lambda=\alpha^{s} U^{s}\left(C^{s}, Y^{s}\right)+\alpha^{w} U\left(C^{w}, Y^{w}\right)-\lambda\left(U^{2}\left(B^{2}-p\left(\frac{Y^{2}}{w_{2}}-\frac{Y^{w}}{w_{1}}\right), Y^{2}\right)-\bar{U}^{2}\right) \\
& +\mu\left(2\left(Y^{2}-B^{2}\right)+\left(Y^{w}-B^{w}\right)+\left(Y^{s}-B^{s}\right)-2 p \frac{Y^{w}}{w_{1}}-p \frac{Y^{w}}{w_{1}}-p \frac{Y^{s}}{w_{1}}\right) \\
& -\beta\left(U^{2}\left(C^{w}, Y^{w}\right)-\bar{U}^{2}\right)-\sigma\left(Y^{s}-B^{s}-p \frac{Y^{s}}{w_{1}}-Y^{w}+B^{w}+p \frac{Y^{w}}{w_{1}}\right)
\end{aligned}
$$

The first constraint (with Lagrange multiplier $\lambda$ ) is the minimum utility requirement for the highskilled person, followed by the budget constraint (with shadow price $\mu$ ). The third restriction (with multiplier $\beta$ ) is the self-selection constraint that the utility that the high-skilled person can obtain by mimicking the low-ability person (with weak preference for leisure) must not exceed the utility level actually intended for him. The equality of transfers to the low-income persons is captured by the last constraint (to which $\sigma$ has been assigned). (For the sake of the derivations 
below note that when differentiating w.r.t. $B^{i}$, the first argument of the utility function is $C^{i}$ and that we always have $\partial C^{i} / \partial B^{i}=1$ for the respective values of $i$.)

Standard first order conditions are derived.

$\Lambda_{B^{2}}=-\lambda U_{C}^{2}-2 \mu=0$,

and

$\Lambda_{Y^{2}}=-\lambda U_{Y}^{2}+\lambda U_{C}^{2} \frac{p}{w_{2}}+2 \mu=0$,

implying that

$\frac{-U_{Y}^{2}}{U_{C}^{2}}=1-\frac{p}{w_{2}}$

The marginal rate of substitution (MRS) between gross and net income on the left hand side expresses the compensation in terms of consumption required to offset the disutility from earning an additional unit of gross income. In other words, this is a money measure of the marginal disutility of acquiring further income. According to (4) the marginal disutility (MRS) should be equated to the extra income actually generated after deducting the cost of day care. Since the latter is a necessary social cost, the right hand side does in fact express the net social income generated by work effort at the margin. Thus (4) is equivalent to the first best efficiency condition, and there is no distortion.

$\Lambda_{B^{s}}=\alpha^{s} U_{C}^{s}-\mu+\sigma=0$

and

$\Lambda_{Y^{s}}=\alpha^{s} U_{Y}^{s}+\mu-\sigma-\mu \frac{p}{w_{1}}+\sigma \frac{p}{w_{1}}=0$

implying that

$$
\frac{-U_{Y}^{s}}{U_{C}^{s}}=\frac{(\mu-\sigma)\left(1-\frac{p}{w_{1}}\right)}{\mu-\sigma}=1-\frac{p}{w_{1}}
$$

The result is similar to that of the high-ability person, and also the labour supply of the lowskilled agent with a strong preference for leisure is undistorted.

$\Lambda_{B^{w}}=\alpha^{w} U_{C}^{w}-\beta U_{C}^{m}-\mu-\sigma=0$

and 
$\Lambda_{Y^{w}}=\alpha^{w} U_{Y}^{w}-\lambda U_{C}^{2} \frac{p}{w_{1}}-\beta U_{Y}^{m}+\mu-2 \mu \frac{p}{w_{1}}-\mu \frac{p}{w_{1}}+\sigma-\sigma \frac{p}{w_{1}}=0$

simplifying to

$-\alpha^{w} U_{Y}^{w}=-\beta U_{Y}^{m}+(\mu+\sigma)\left(1-\frac{p}{w_{1}}\right)$

and

$\alpha^{w} U_{C}^{w}=\beta U_{C}^{m}+(\mu+\sigma)=0$

Dividing on both sides we obtain

$\frac{-U_{Y}^{w}}{U_{C}^{w}}=\frac{-\beta U_{Y}^{m}+(\mu+\sigma)\left(1-\frac{p}{w_{1}}\right)}{\beta U_{C}^{m}+\mu+\sigma}$

which can be reformulated as

$\frac{-U_{Y}^{w}}{U_{C}^{w}}\left(\beta U_{C}^{m}+\mu+\sigma\right)=-\beta U_{Y}^{m}+(\mu+\sigma)\left(1-\frac{p}{w_{1}}\right)$.

Straightforward manipulations yield the expression

$\frac{-U_{Y}^{w}}{U_{C}^{w}}\left(1+\frac{\mu+\sigma}{\beta U_{C}^{m}}\right)=\frac{-\beta U_{Y}^{m}}{\beta U_{C}^{m}}+\frac{(\mu+\sigma)\left(1-\frac{p}{w_{1}}\right)}{\beta U_{C}^{m}}$

or equivalently

$\frac{-U_{Y}^{w}}{U_{C}^{w}}\left(\frac{\mu+\sigma}{\beta U_{C}^{m}}\right)=\frac{-U_{Y}^{m}}{U_{C}^{m}}-\frac{-U_{Y}^{w}}{U_{C}^{w}}+\frac{(\mu+\sigma)\left(1-\frac{p}{w_{1}}\right)}{\beta U_{C}^{m}}$

A further division and using the notations $\rho=\beta U_{C}^{m} /(\mu+\sigma)$ and $M R S=-U_{Y} / U_{C}$ we obtain the expression

$$
M R S^{w}=\rho\left(M R S^{m}-M R S^{w}\right)+1-\frac{p}{w_{1}}<1-\frac{p}{w_{1}}
$$

since $M R S^{m}-M R S^{w}<0$, which is the standard assumption that the more high-skilled type has the flatter indifference curve through any given point in $Y, B$-space. It follows that the type of person with weak preference for leisure has a marginal disutility of acquiring further income, 
which is less than the net social income that can actually be obtained. Hence the labour supply is distorted.

Let us interpret these findings in terms of marginal tax rates. The high-skilled person and the low-skilled person with a strong preference for leisure will remain un-mimicked in the absence of any distortion of their consumption-leisure bundles. Defining the income tax as $T(Y)=Y-B(Y)$ and the total tax net of the public day care provision as $\tau(Y)=Y-B(Y)-p Y / w=T(Y)-p Y / w$, where the transfer in terms of day care enters as a negative tax, we find that $\tau^{\prime}(Y)=T^{\prime}(Y)-p / w=0$ for these two types of agents, whereas their marginal income tax rates become $T^{\prime}\left(Y^{2}\right)=p / w^{2}$ and $T^{\prime}\left(Y^{s}\right)=p / w^{s}$, respectively ${ }^{8}$. The implication is that these persons face the same marginal prices as in a situation with no public provision of day care. Rather than buying day care in the market they simply pay for it via their taxes. Since resources must be allocated to day-care, every hour of work inflicts a real cost of $p$ on society, which should be reflected in the budget constraints to provide the right incentives for labour supply and making sure that $M R S=M R T$ in terms of consumption and leisure. In other words the marginal income of further work effort should be equated to the cost in terms of marginal disutility (in money terms) and the cost of providing the necessary day care.

The consumption-leisure bundle of the low-skilled group with weak preference must be distorted in order to prevent these agents from being mimicked. Their marginal income tax is $T^{\prime}\left(Y^{w}\right)=\rho\left(M R S^{w}-M R S^{m}\right)+p / w_{1}, \quad$ and the marginal total tax is $\tau^{\prime}\left(Y^{w}\right)=T^{\prime}\left(Y^{w}\right)-p / w_{1}=\rho\left(M R S^{w}-M R S^{m}\right)$. We see that the marginal effect on total tax payments, taking account of the transfer in kind, is of the same form as the marginal income tax in the pure income tax system. However, now there is an additional term, $p / w_{1}$, in the expression for the marginal income tax. Also the low-skilled person with a weak preference for leisure now pays via the tax bill for the day care he obtains. Hence, for all actual persons public provision makes the cost of obtaining day care no different than if it were purchased in the market. In either case the consumers face the real cost of day care, as is socially desirable since day care is a true cost of supplying labour. The market price and the extra tax, perceived as earmarked for day care,

\footnotetext{
${ }^{8}$ We adopt the standard approach of equating the marginal disutility, or marginal rate of substitution, to the marginal income net of tax, i.e. $-U_{Y} / U_{B}=1-T^{\prime}(Y)$ by which the marginal tax rate is implicitly defined.
} 
yield the same labour market disincentives. Only if a person were to mimic, would the public scheme be different than a market system as a mimicker, via the tax system, would be forced to pay for an amount of day care equal to that demanded by the low-skill person with a weak preference for leisure, and exceeding the need of the mimicker. This is the crucial property of the public provision system as it is indeed the capability of alleviating the self-selection constraint that is the very justification for the public provision in our context. 


\section{References}

Allingham, M. (1975). “Towards an Ability Tax”, Journal of Public Economics 4, 361-376.

Besley, T. and S. Coate (1991). "Public Provision of Private Goods and the Redistribution of Income." American Economic Review 81, 979-984.

Blackorby, C. and D. Donaldson (1988). "Cash versus Kind, Self-selection and Efficient Transfers." American Economic Review 78, 691-700.

Blomquist, S. and V. Christiansen (1995). "Public Provision of Private Goods as a Redistributive Device in an Optimum Income Tax Model." Scandinavian Journal of Economics 97, 547567.

Blomquist, S. and V. Christiansen (1998a). "Topping Up or Opting Out? The Optimal Design of Public Provision Schemes”. International Economic Review 39, 399-411.

Blomquist, S. and V. Christiansen (1998b). "Price Subsidies Versus Public Provision". International Tax and Public Finance 5, 283-306.

Blomquist, S. and V. Christiansen (1999). "The Political Economy of Publicly Provided Private Goods.” Journal of Public Economics 73, 31-54.

Boadway, R. and M. Marchand (1995). "The Use of Public Expenditures for Redistributive Purposes"." Oxford Economic Papers 47, 45-59.

Boadway, R. M. Marchand and M. Sato (1998). "Subsidies versus Public Provision of Private Goods as Instruments for Redistribution." Scandinavian Journal of Economics 100, 545564.

Boadway, R., M. Marchand, P. Pestieau and M.d.m. Racionero (2002). "Optimal Redistribution with Heterogeneous Preferences for Leisure," Journal of Public Economic Theory 4, 475498.

Bossert, W. (1995). "Redistribution Mechanisms Based on Individual Characteristics," Mathematical and Social Sciences 29, 1-17.

Cremer, H. and F. Gahvari (1997). "In-kind Transfers, Self-selection and Optimal Tax Policy." European Economic Review 41, 97-114.

Cuff, K. (2000). "Optimality of Workfare with Heterogeneous Preferences.” Canadian Journal of Economics 33, 149-174.

Epple, D. and R.E. Romano (1996). "Public Provision of Private Goods.” Journal of Political Economy 104, 57-84. 
Gouveia, M. (1997). "Majority Rule and the Public Provision of a Private Good." Public Choice 93, 221-244.

Jordahl, H. and L. Micheletto (2002). “Optimal Taxation and Horizontal Equity.” Working paper 2002:19, Department of Economics, Uppsala University

Mirrlees, J.A. (1971). "An Exploration in the Theory of Optimum Income Taxation." Review of Economic Studies 38, 175-208.

Nichols, A.L. and R.J. Zeckhauser (1982). "Targeting Transfers through Restrictions on Recipients." American Economic Review Papers and Proceedings 72, 372-377.

Stern, N.H. (1982). "Optimum Income Taxation with Errors in Administration." Journal of Public Economics 17, 181-211.

Stiglitz, J.E. (1982). "Self-Selection and Pareto Efficient Taxation." Journal of Public Economics $17,213-240$.

Tarkianen, R. and M. Tuomala (1999). "Optimal Nonlinear Income Taxation with a TwoDimensional Population; A Computational Approach.” Computational Economics 13, 116. 


\title{
CESifo Working Paper Series
}

\author{
(for full list see www.cesifo.de)
}

869 M. Hashem Pesaran, Estimation and Inference in Large Heterogenous Panels with Cross Section Dependence, February 2003

870 Luis H. R. Alvarez and Erkki Koskela, On the Tree-Cutting Problem under Interest Rate and Forest Value Uncertainty, February 2003

871 Norbert Berthold and Rainer Fehn, Unemployment in Germany: Reasons and Remedies, February 2003

872 Clemens Fuest, Bernd Huber, and Philipp Tilleßen, Tax Policy and Entrepreneurship in the Presence of Asymmetric Information in Capital Markets, February 2003

873 Eytan Sheshinski, Optimum and Risk-Class Pricing of Annuities, February 2003

874 Willi Leibfritz, Paul O'Brien and Jean-Christophe Dumont, Effects of Immigration on Labour Markets and Government Budgets - An Overview, February 2003

875 M. Hashem Pesaran and Allan Timmermann, How Costly is it to Ignore Breaks when Forecasting the Direction of a Time Series?, February 2003

876 Thorvaldur Gylfason and Gylfi Zoega, Education, Social Equality and Economic Growth: A View of the Landscape, February 2003

877 Robin Boadway and Jean-François Tremblay, Public Economics and Startup Entrepreneurs, February 2003

878 Erkki Koskela and Roope Uusitalo, The Un-Intended Convergence: How the Finnish Unemployment Reached the European Level, February 2003

879 Robert Fenge and Volker Meier, Pensions and Fertility Incentives, February 2003

880 Eytan Sheshinski, Note on Income Taxation and Occupational Choice, February 2003

881 A B Atkinson, Income Inequality in OECD Countries: Data and Explanations, February 2003

882 Thomas Gehrig and Rune Stenbacka, Venture Cycles: Theory and Evidence, February 2003

883 Ralf Becker and Thomas Hellmann, The Genesis of Venture Capital - Lessons from the German Experience, March 2003

884 Eytan Sheshinski, Note on the Optimum Pricing of Annuities, March 2003 
885 Paul De Grauwe and Magdalena Polan, Globalisation and Social Spending, March 2003

886 F. van der Ploeg, Do Social Policies Harm Employment and Growth?, March 2003

887 Mirjam van Praag, Initial Capital Constraints Hinder Entrepreneurial Venture Performance: An empirical analysis, March 2003

888 Bernard Steunenberg, Coordinating Sectoral Policymaking: Searching for Countervailing Mechanisms in the EU Legislative Process, March 2003

889 Eytan Sheshinski, Optimum Delayed Retirement Credit, March 2003

890 Frederick van der Ploeg, Rolling Back the Public Sector - Differential effects on employment, investment and growth, March 2003

891 Paul De Grauwe and Marc-Alexandre Sénégas, Monetary Policy in EMU when the Transmission is Asymmetric and Uncertain, March 2003

892 Steffen Huck and Kai A. Konrad, Strategic Trade Policy and the Home Bias in Firm Ownership Structure, March 2003

893 Harry Flam, Turkey and the EU: Politics and Economics of Accession, March 2003

894 Mathias Hoffmann and Ronald MacDonald, A Re-examination of the Link between Real Exchange Rates and Real Interest Rate Differentials, March 2003

895 Badi H. Baltagi, Espen Bratberg, and Tor Helge Holmås, A Panel Data Study of Physicians' Labor Supply: The Case of Norway, March 2003

896 Dennis C. Mueller, Rights and Citizenship in the European Union, March 2003

897 Jeremy Edwards, Gains from Trade in Tax Revenue and the Efficiency Case for Trade Taxes, March 2003

898 Rainer Fehn and Thomas Fuchs, Capital Market Institutions and Venture Capital: Do They Affect Unemployment and Labour Demand?, March 2003

899 Ronald MacDonald and Cezary Wójcik, Catching Up: The Role of Demand, Supply and Regulated Price Effects on the Real Exchange Rates of Four Accession Countries, March 2003

900 R. Selten, M. Schreckenberg, T. Pitz, T. Chmura, and S. Kube, Experiments and Simulations on Day-to-Day Route Choice-Behaviour, April 2003

901 Stergios Skaperdas, Restraining the Genuine Homo Economicus: Why the Economy Cannot be Divorced from its Governance, April 2003

902 Yin-Wong Cheung, Menzie D. Chinn, and Antonio Garcia Pascual, What Do We Know about Recent Exchange Rate Models? In-Sample Fit and Out-of-Sample Performance Evaluated, April 2003 
903 Mika Widgrén, Enlargements and the Principles of Designing EU - Decision-Making Procedures, April 2003

904 Phornchanok Cumperayot, Dusting off the Perception of Risk and Returns in FOREX Markets, April 2003

905 Kai A Konrad, Inverse Campaigning, April 2003

906 Lars P. Feld and Stefan Voigt, Economic Growth and Judicial Independence: Cross Country Evidence Using a New Set of Indicators, April 2003

907 Giuseppe Bertola and Pietro Garibaldi, The Structure and History of Italian Unemployment, April 2003

908 Robert A.J. Dur and Otto H. Swank, Producing and Manipulating Information, April 2003

909 Christian Gollier, Collective Risk-Taking Decisions with Heterogeneous Beliefs, April 2003

910 Alexander F Wagner, Mathias Dufour, and Friedrich Schneider, Satisfaction not Guaranteed - Institutions and Satisfaction with Democracy in Western Europe, April 2003

911 Ngo Van Long, Raymond Riezman, and Antoine Soubeyran, Trade, Wage Gaps, and Specific Human Capital Accumulation, April 2003

912 Andrea Goldstein, Privatization in Italy 1993-2002: Goals, Institutions, Outcomes, and Outstanding Issues, April 2003

913 Rajshri Jayaraman and Mandar Oak, The Signaling Role of Municipal Currencies in Local Development, April 2003

914 Volker Grossmann, Managerial Job Assignment and Imperfect Competition in Asymmetric Equilibrium, April 2003

915 Christian Gollier and Richard Zeckhauser, Collective Investment Decision Making with Heterogeneous Time Preferences, April 2003

916 Thomas Moutos and William Scarth, Some Macroeconomic Consequences of Basic Income and Employment Subsidies, April 2003

917 Jan C. van Ours, Has the Dutch Miracle Come to an End?, April 2003

918 Bertil Holmlund, The Rise and Fall of Swedish Unemployment, April 2003

919 Bernd Huber and Marco Runkel, Optimal Design of Intergovernmental Grants under Asymmetric Information, April 2003

920 Klaus Wälde, Endogenous Business Cycles and Growth, April 2003 
921 Ramon Castillo and Stergios Skaperdas, All in the Family or Public? Law and Appropriative Costs as Determinants of Ownership Structure, April 2003

922 Peter Fredriksson and Bertil Holmlund, Improving Incentives in Unemployment Insurance: A Review of Recent Research, April 2003

923 Bernard M.S. van Praag and Adam S. Booij, Risk Aversion and the Subjective Time Discount Rate: A Joint Approach, April 2003

924 Yin-Wong Cheung, Kon S. Lai, and Michael Bergman, Dissecting the PPP Puzzle: The Unconventional Roles of Nominal Exchange Rate and Price Adjustment, April 2003

925 Ugo Trivellato and Anna Giraldo, Assessing the 'Choosiness' of Job Seekers. An Exploratory Approach and Evidence for Italy, April 2003

926 Rudi Dornbusch and Stanley Fischer, International Financial Crises, April 2003

927 David-Jan Jansen and Jakob de Haan, Statements of ECB Officials and their Effect on the Level and Volatility of the Euro-Dollar Exchange Rate, April 2003

928 Mario Jametti and Thomas von Ungern-Sternberg, Assessing the Efficiency of an Insurance Provider - A Measurement Error Approach, April 2003

929 Paolo M. Panteghini and Guttorm Schjelderup, Competing for Foreign Direct Investments: A Real Options Approach, April 2003

930 Ansgar Belke, Rainer Fehn, and Neil Foster, Does Venture Capital Investment Spur Employment Growth?, April 2003

931 Assar Lindbeck, Sten Nyberg, and Jörgen W. Weibull, Social Norms and Welfare State Dynamics, April 2003

932 Myrna Wooders and Ben Zissimos, Hotelling Tax Competition, April 2003

933 Torben M. Andersen, From Excess to Shortage - Recent Developments in the Danish Labour Market, April 2003

934 Paolo M. Panteghini and Carlo Scarpa, Irreversible Investments and Regulatory Risk, April 2003

935 Henrik Jacobsen Kleven and Claus Thustrup Kreiner, The Marginal Cost of Public Funds in OECD Countries. Hours of Work Versus Labor Force Participation, April 2003

936 Klaus Adam, George W. Evans, and Seppo Honkapohja, Are Stationary Hyperinflation Paths Learnable?, April 2003

937 Ulrich Hange, Education Policy and Mobility: Some Basic Results, May 2003

938 Sören Blomquist and Vidar Christiansen, Is there a Case for Public Provision of Private Goods if Preferences are Heterogeneous? An Example with Day Care, May 2003 